\title{
KEDUDUKAN DAN ARTI PENTING PEMBUKAAN UUD 1945
}

\author{
Rudy \\ Bagian Hukum Tata Negara Fakultas Hukum Universitas Lampung \\ Rudy.1981@fh.unila.ac.id
}

\begin{abstract}
Abstrak
Tulisan ini bertujuan untuk menjelaskan kedudukan dan arti penting Pembukaan UUD 1945 dalam kehidupan berbangsa dan bernegara. Dalam konteks tujuan tersebut, tulisan ini memuat diskusi mengenai apakah pembukaan tersebut? Bagaimanakah kedudukan dari pembukaan tersebut dan apakah peran pembukaan dalam peradilan konstitusi dan design konstitusi? Dan mengapa negara menambahkan pembukaan pada konstitusi? Dilihat dari sudut teori ketatanegaraan, pembukaan, preambule, atau mukadimah dalam setiap dokumen konstitusi selalu berisikan pernyataan yang singkat tapi sungguh padat. Di dalamnya tertuang visi, misi, dan nilai-nilai dasar sebuah institusi atau organisasi sebagai wadah kebersamaan yang hendak dibangun dan dijalankan bersama. Selain itu juga merupakan pengantar hidmat berisi ide-ide politik, moral, dan keagamaan yang hendak dikemukakan oleh konstitusi tersebut. Pembukaan ini lebih mengandung karakter ideologis daripada karakter hukum. Dalam konteks Indonesia, Pembukaan UUD 1945 adalah bagian terpenting dari UUD 1945 yang disepakati oleh MPR 1999 untuk tidak diubah sama sekali. Pembukaan dikatakan sebagai bagian terpenting karena disanalah tertuang norma fundamental negara (staatsfundamental norm), tujuan bangsa dan tujuan bangsa inilah merupakan hasil kontrak kenegaraan antara rakyat dan negara.
\end{abstract}

Kata kunci : kedudukan, arti penting, dan Pembukaan UUD 1945

\section{Pendahuluan}

Konstitusi merupakan back
bone dalam setiap bangunan
kenegaraan. Istilah konstitusi
sebenarnya sudah ada sejak zaman
Yunani dimana terdapat Konstitusi
Athena. Keberadaan Konstitusi
Athena pada saat itu dipandang
sebagai alat demokrasi yang
sempurna. ${ }^{1}$ Pada masa kekaisaran
Romawi, istilah konstitusi digunakan

${ }^{1}$ Ahmad Sukardja, Piagam Madinah \& Undang-Undang Dasar NRI 1945, (Jakarta: Sinar Grafika, 2012), hal. 34 untuk menyebut the act of legislation by emperor. ${ }^{2}$

Dalam kosakata bahasa Indonesia, istilah konstitusi mempunyai dua makna yaitu segala ketentuan dan aturan tentang ketatanegaraan dan UUD suatu negara. UUD menurut Kamus Besar Bahasa Indonesia berarti undangundang yang menjadi dasar semua undang-undang dan peraturan lain di suatu negara yang mengatur bentuk, sistem pemerintahan, pembagian

\footnotetext{
2 Charles Howard McIllwain, Constitutionalism : Ancient and Modern, (Cornell University Press, 1947). Hlm. 23.
} 
kekuasaan, wewenang badan pemerintahan. $^{3}$

Dalam kepustakaan Belanda istilah konstitusi dikenal dengan sebutan Grondwet atau undangundang yang menjadi dasar dari segala hukum. ${ }^{4}$ Konsep ini sejalan dengan apa yang dikemukakan oleh Hans Kelsen mengenai konstitusi. Menurut Hans Kelsen, konstitusi yang biasa disebut sebagai hukum fundamental negara merupakan dasar dari tatanan hukum nasional. Sebagai dasar dari tatanan hukum nasional, konstitusi menjadi sumber validitas norma hukum nasional. Kelsen menerangkan bahwa ditinjau dari teori politik, konsep konstitusi juga mencakup norma-norma yang mengatur pembentukan dan kompetensi dari organ-organ eksekutif dan yudikatif tertinggi. ${ }^{5}$

James Bryce dari sudut pandang politik mendefinisikan konstitusi sebagai kerangka politik yang terorganisasi berdasarkan hukum mencakup di dalamnya kelembagaan negara dengan fungsi dan hak-hak yang jelas. CF Strong mendefinisikan konstitusi sebagai kumpulan prinsip-prinsip yang mengatur mengenai kekuasaan pemerintah, hak-hak warga, dan hubungan antara pemerintah dan warga. Kedua ahli tata negara ini merepresentasikan tradisi hukum common law yang lebih menekankan pada rights atau hak warga negara.

Dari ranah tradisi civil law, Herman Heller membagi konstitusi menjadi 3 (tiga) pengertian

\footnotetext{
${ }^{3}$ Departemen Pendidikan Nasional, Kamus Besar Bahasa Indonesia, (Jakarta: Balai Pustaka, 2002) hal. 590, 1245.

${ }^{4}$ Ahmad Sukardja, Op. Cit., hal. 36.

${ }^{5}$ Hans Kelsen, Teori Umum tentang Hukum dan Negara, (Bandung: Penerbit Nusamedia, 2009), hal. 365.
}

berdasarkan tahapan perkembangan konstitusi, yaitu:
1. Konstitusi dalam pengertian politis sosiologis. ${ }^{6}$
2. Konstitusi dalam pengertian yuridis. $^{7}$

3. Konstitusi dalam arti UUD tertulis. $^{8}$

Sejalan dengan Heller,

Ferdinand Lasalle juga membagi konstitusi dalam pengertian politis sosiologis dan pengertian yuridis. Pengertian politis sosiologis menurut Lasalle merupakan suatu sintesis kekuatan-kekuatan nyata dalam suatu negara. ${ }^{9}$ Sedangkan pengertian

\footnotetext{
${ }^{6}$ Pada tingkat pertama ini, konstitusi tumbuh dalam pengertian sosial-politik. Ide-ide konstitusional dikembangkan karena memang mencerminkan keadaan sosial politik dalam masyarakat yang bersangkutan pada saat itu. Konstitusi pada tahap ini dapat digambarkan sebagai kesepakatan-kesepakatan politik yang belum dituangkan dalam bentuk hukum tertentu, melainkan tercerminkan dalam perilaku nyata dalam kehidupan kolektif warga masyarakat.

${ }^{7}$ Pada tahap kedua ini, konstitusi sudah diberi bentuk hukum tertentu, sehingga perumusan normatifnya menuntut pemberlakuan yang dapat dipaksakan. Konstitusi dalam pengertian sosial-politik yang dilihat sebagai kenyataan tersebut di atas, dianggap harus berlaku dalam kenyataan. Oleh karena itu, setiap pelanggaran terhadapnya haruslah dapat dikenai ancaman sanksi yang pasti;

${ }^{8}$ Konstitusi dalam pengertian Peraturan Tertulis. Pengertian yang terakhir ini merupakan tahap terakhir atau yang tertinggi dalam perkembangan pengertian rechtsverfassung yang muncul sebagai akibat pengaruh aliran kodifikasi yang menghendaki agar berbagai norma hukum dapat dituliskan dalam naskah yang bersifat resmi. Tujuannya adalah untuk maksud mencapai kesatuan hukum atau unifikasi hukum (rechtseineheid), kesederhanaan hukum (rechtsvereenvoudiging), dan kepastian hukum (rechtszekerheid).

9 Misalnya raja, parlemen, kabinet, kelompok-kelompok penekan (preassure groups), partai politik, dan sebagainya. Dinamika hubungan di antara kekuatan-
} 
yuridis menurutnya adalah naskah yang memuat bangunan negara dan sendi-sendi pemerintahan. ${ }^{10}$

Sementara itu, KC Wheare dalam bukunya Modern Constitution membagi pengertian konstitusi kedalam pengertian luas dan pengertian sempit. pengertian konstitusi dalam arti luas menurut Wheare adalah suatu sistem pemerintahan negara dan himpunan norma yang mendasari dan mengatur suatu pemerintahan; norma-norma tersebut terdiri dari norma yuridis dan norma non-yuridis atau extralegal. ${ }^{11}$ Pengertian konstitusi dalam arti sempit menurut Wheare adalah kumpulan peraturan-peraturan yang legal dalam ketatanegaraan suatu negara yang terhimpun dalam dokumen atau beberapa dokumen yang saling terkait. ${ }^{12}$

Konstitusi pada dasarnya terdiri dari Pembukaan Konstitusi dan Batang Tubuh Konstitusi. Berbicara mengenai pembukaan dalam konstitusi negara sedikit banyak kita membicarakan mengenai apakah pembukaan tersebut? bagaimanakah kedudukan dari pembukaan tersebut dan apakah peran pembukaan dalam peradilan konstitusi dan design konstitusi? Dan mengapa negara menambahkan pembukaan pada konstitusi?

Pertanyaan-pertanyaan di atas merupakan pertanyaan-pertanyaan

kekuatan politik yang nyata itulah sebenarnya apa yang dipahami sebagai konstitusi

${ }^{10} \mathrm{Di}$ samping sebagai cermin hubungan antar aneka kekuatan politik yang nyata dalam masyarakat (de riele machtsfactoren), konstitusi itu pada pokoknya adalah apa yang tertulis di atas kertas UUD mengenai lembaga-lembaga negara, prinsip-prinsip, dan sendi-sendi dasar pemerintahan negara

11 KC Wheare, Modern Constitution, (Oxford University Press, 1951), p. 1.

${ }^{12}$ Ibid. p. 2 yang jarang sekali mendapat perhatian di studi-studi mengenai ketatanegaraan di Indonesia. Dapatlah kita membuka buku-buku ketatanegaraan dan menemukan bahwa topik ini merupakan topik yang tidak mendapat tempat yang penting dalam studi ketatanegaraan saat ini.

Mengenai suatu Konstitusi atau Undang-Undang Dasar dapat dikatakan, bahwa suatu pembukaan berisi lebih dari pada alasan pembentukan saja. Oleh karena konstitusi sebagai sumber pertama dari Hukum Tata Negara mendasari undang-undang biasa, bahkan mendasari seluruh hidup ketatanegaraan dari suatu Negara, maka adalah layak, apabila dalam pembukaan suatu konstitusi termuat juga dasar-dasar bagi berdirinya Negara yang bersangkutan. Mengingat sifat konstitusi sebagai hukum dasar yang mendasari segala hukum yang berlaku di dalam negara, maka layak pula, jika pembukaan suatu konstitusi juga memuat filsafat-hukum yang dianut dalam negara itu. ${ }^{13}$

\section{Teori Ketatanegaraan mengenai Pembukaan}

Apakah pembukaan suatu konstitusi dan bagaimanakah klasifikasinya? Liav Orgad 14 membagi definisi pembukaan suatu konstitusi kedalam terminologi formal dan substansif. Menurut terminologi formal, pembukaan

\footnotetext{
${ }^{13}$ Wirjono Prodjodikoro, Azas-Azas Hukum Tata Negara di Indonesia, (Jakarta: Penerbit Dian Rakjat, 1983), hal. 32

14 Liav Orgad, The Preambule in Constitutional Interpretation, (International Journal of Constitutional Law 8, Oxford University, 2010).
} 
merupakan suatu pengantar untuk mengenal konstitusi yang biasanya ditandai dengan kata "pembukaan" atau alternatif lainnya. Klasifikasi formal ini menyediakan sarana identifikasi posisi pembukaan yang ringkas dan teknis. Secara substansif, pembukaan berisi sejarah dibalik perumusan suatu konstitusi, prinsipprinsip dan nilai-nilai fundamental.

Liav Orgad menambahkan bahwa materi muatan pembukaan dapat diklasifikasikan ke dalam 5 kategori: ${ }^{15}$

1. Kedaulatan

2. Sejarah

3. Tujuan dan Cita Bangsa

4. Identitas Nasional

5. Agama atau Ketuhanan

Dalam konteks klasifikasi konstitusi menurut Carl Schmidt sebagaimana dikutif oleh Jimly Asshidiqie, 16 pembukaan dapat dijelaskan dalam konteks konstitusi dalam arti materiil (constitutie in materiele zin). Konstitusi dalam arti materiil adalah konstitusi yang dilihat dari segi isinya. Isi konstitusi itu menyangkut hal-hal yang bersifat dasar atau pokok bagi rakyat dan negara. Karena pentingnya hal-hal yang bersifat dasar atau pokok bagi rakyat dan negara tersebut, maka untuk membuat konstitusi itu diperlukan prosedur yang khusus. Prosedur khusus itu dapat dilakukan sepihak, dua pihak, atau banyak pihak. Prosedur itu dilakukan sepihak karena ia merupakan kehendak dari satu orang yang menamakan dirinya eksponen dari rakyat atau seorang diktator. Bisa juga dilakukan oleh dua pihak karena

\footnotetext{
${ }^{15}$ Ibid.

${ }^{16}$ Jimly Asshidiqie, Pengantar Hukum Tata Negara Jilid 1, Sekretariat Jenderal dan Kepaniteraan Mahkamah Konstitusi, Jakarta: 2006, hal. 131.
}

Konstitusi merupakan hasil persetujuan dari dua golongan dalam masyarakat yaitu misalnya antara rakyat di satu pihak dan Raja di lain pihak pada zaman abad pertengahan. Sedangkan, bisa banyak pihak dikarenakan Konstitusi itu merupakan hasil persetujuan dari banyak pihak yaitu antara wakilwakil rakyat yang duduk dalam suatu badan yang bertugas membuat Konstitusi (badan Konstitusi).

Masdar Farid Mas'udi 17 menyatakan bahwa Pembukaan, Preambule, atau Mukadimah dalam setiap dokumen konstitusi selalu berisikan pernyataan yang singkat tapi sungguh padat. Di dalamnya tertuang visi, misi, dan nilai-nilai dasar sebuah institusi atau organisasi sebagai wadah kebersamaan yang hendak dibangun dan dijalankan bersama. Sementara itu Hans Kelsen menyatakan bahwa pembukaan adalah bagian tradisional konstitusi yang merupakan pengantar hidmat berisi ide-ide politik, moral, dan keagamaan yang hendak dikemukakan oleh konstitusi tersebut. Pembukaan ini lebih mengandung karakter ideologis daripada karakter hukum. ${ }^{18}$

Pemikiran mendasar tentang jatidiri bangsa, peranannya dalam memberikan identitas sistem kenegaraan dan sistem hukum, dikemukakan juga oleh Carl von Savigny dengan teorinya yang amat terkenal sebagai Volksgeist yang dapat disamakan sebagai jiwa bangsa dan atau jatidiri nasional. Demikian pula di Perancis dengan "teori 'raison d' etat' (reason of state) yang menentukan eksistensi suatu bangsa

\footnotetext{
${ }^{17}$ Masdar Farid Mas'udi,.. Op. Cit., hal. 3.

${ }^{18}$ Hans Kelsen, Teori Umum.., Op. Cit., hal. 367
} 
dan negara (the rise of souvereign, independent, and nation state)". ${ }^{19}$

Dari teori-teori di atas, bagaimanakah sesungguhnya kedudukan dan arti penting Pembukaan UUD 1945 sendiri? Tulisan ini akan mendeskripsikan, mengupas, dan berusaha menjelaskan kedudukan dan arti penting UUD 1945.

\section{Pembukaan UUD 1945}

PEMBUKAAN

\section{( P r e a m b u l e )}

Bahwa sesungguhnya Kemerdekaan itu ialah hak segala bangsa dan oleh sebab itu, maka penjajahan di atas dunia harus dihapuskan, karena tidak sesuai dengan perikemanusiaan dan peri-keadilan.

Dan perjuangan pergerakan kemerdekaan Indonesia telah sampailah kepada saat yang berbahagia dengan selamat sentausa mengantarkan rakyat Indonesia ke depan pintu gerbang kemerdekaan Negara Indonesia, yang merdeka, bersatu, berdaulat, adil dan makmur.

Atas berkat rakhmat Allah Yang Maha Kuasa dan dengan didorongkan oleh keinginan luhur, supaya berkehidupan kebangsaan yang bebas, maka rakyat Indonesia menyatakan dengan ini kemerdekaannya.

Kemudian daripada itu untuk membentuk suatu Pemerintah Negara Indonesia yang melindungi segenap bangsa Indonesia dan seluruh tumpah darah Indonesia dan untuk memajukan kesejahteraan umum, mencerdaskan kehidupan bangsa, dan ikut melaksanakan

\footnotetext{
${ }^{19}$ Edgar Bodenheimer, Jurisprudence: The method and philosophy of law, (Cambridge: Harvard University Press, 1962), p. 71-72
}

ketertiban dunia yang berdasarkan kemerdekaan, perdamaian abadi dan keadilan sosial, maka disusunlah Kemerdekaan Kebangsaan Indonesia itu dalam suatu Undang-Undang Dasar Negara Indonesia, yang terbentuk dalam suatu susunan Negara Republik Indonesia yang berkedaulatan rakyat dengan berdasar kepada Ketuhanan Yang Maha Esa, Kemanusiaan yang adil dan beradab, Persatuan Indonesia dan Kerakyatan yang dipimpin oleh hikmat kebijaksanaan dalam Permusyawaratan/Perwakilan, serta dengan mewujudkan suatu Keadilan sosial bagi seluruh rakyat Indonesia.

\section{Konteks Indonesia}

Sebagai wujud perjanjian sosial tertinggi, konstitusi memuat cita- cita yang akan dicapai dengan pembentukan negara dan prinsipprinsip dasar pencapaian cita-cita tersebut. UUD 1945 sebagai konstitusi bangsa Indonesia merupakan dokumen hukum dan dokumen politik yang memuat citacita, dasar-dasar, dan prinsip-prinsip penyelenggaraan kehidupan nasional. Pembukaan dan pasal-pasal adalah satu kesatuan norma-norma konstitusi. Walaupun pembukaan memiliki tingkat abstraksi yang lebih tinggi dibanding pasal-pasal, namun tidak dapat dikatakan bahwa pembukaan memiliki kedudukan lebih tinggi dari pasal-pasal. Keduanya adalah norma-norma konstitusi yang supreme dalam tata hukum nasional (national legal order). ${ }^{20}$

\footnotetext{
20 Jimly Asshidiqie, 2005, Implikasi Perubahan UUD 1945 terhadap Pembangunan Hukum Nasional, Jakarta: Mahkamah Konstitusi RI, hal. 18.
} 
Dalam konteks Indonesia, Augustinus Simanjuntak 21 menyatakan dengan lugas bahwa Pembukaan UUD 1945 adalah bagian terpenting dari UUD 1945 yang disepakati oleh MPR 1999 untuk tidak diubah sama sekali. Pembukaan dikatakan sebagai bagian terpenting karena disanalah tertuang Pancasila yang merupakan norma fundamental negara (staatsfundamental norm). Penulis sejalan dengan pendapat Augustinus Simanjuntak menganggap pembukaan mempunyai nilai yang sangat penting karena pembukaan memuat cita hukum ${ }^{22}$ dan cita bangsa.

Namun demikian penulis tidak sependapat dengan pandangan bahwa pembukaan penting karena memuat pancasila karena bagaimanapun juga dalam konteks UUD 1945, cita hukum dan tujuan bangsa tidak disebut sebagai Pancasila. Pentingnya pembukaan lebih disebabkan karena disanalah letak tujuan bangsa dan tujuan bangsa inilah merupakan hasil kontrak kenegaraan antara rakyat dan negara.

Tujuan bangsa ini termuat dalam Pembukaan UUD 1945 alenia keempat, yaitu (a) melindungi segenap bangsa Indonesia dan seluruh tumpah darah Indonesia; (b)

21 Augustinus Simanjuntak, Refleksi 60 Tahun UUD 1945, Harian Surabaya Post, 12 Agustus 2005.

${ }^{22}$ Menurut Rudolf Stammier, cita hukum adalah adalah konstruksi pikiran yang merupakan keharusan untuk mengarahkan hukum pada cita-cita yang diinginkan masyarakat, selanjutnya Gustav Radbruch seorang ahli filsafat hukum seperti Stammler dari aliran Neokantian menyatakan bahwa cita hukum berfungsi sebagai tolak ukur yang bersifat regulative dan konstruktif, tanpa cita hukum, hukum akan kehilangan maknanya. memajukan kesejahteraan umum; (c) mencerdaskan kehidupan bangsa; dan (d) ikut melaksanakan ketertiban dunia yang berdasarkan kemerdekaan, perdamaian abadi, dan keadilan sosial. Cita-cita tersebut akan dilaksanakan dalam suatu susunan Negara Republik Indonesia yang berdiri di atas lima dasar fundamental.

Untuk mencapai cita-cita tersebut dan melaksanakan penyelenggaraan negara berdasarkan Pancasila, UUD 1945 telah memberikan kerangka susunan kehidupan bermasyarakat, berbangsa, dan bernegara. Norma-norma dalam UUD 1945 tidak hanya mengatur kehidupan politik tetapi juga kehidupan ekonomi dan sosial. Hal ini karena para pendiri bangsa menghendaki bahwa rakyat Indonesia berdaulat secara penuh, bukan hanya kedaulatan politik. Maka UUD 1945 merupakan konstitusi politik, konstitusi ekonomi, dan konstitusi sosial yang harus menjadi acuan dan landasan secara politik, ekonomi, dan sosial, baik oleh negara (state), masyarakat (civil society), ataupun pasar (market). ${ }^{23}$

Mutatis mutandis dari hal tersebut di atas, Komisi Konstitusi tentang perubahan Undang-Undang Dasar Negara RI tahun 1945 menyimpulkan bahwa kedudukan dan fungsi konstitusi adalah sebagai berikut: ${ }^{24}$

1. Konstitusi berfungsi sebagai dokumen nasional (national document) yang mengandung perjanjian luhur, berisi

\footnotetext{
${ }^{23}$ Jimly Asshidiqie, op. cit. hal. 19

${ }^{24}$ Majelis Permusyawaratan Rakyat, Buku I, Naskah Akademik Kajian Komprehensif Komisi Konstitusi tentang Perubahan Undang-Undang Dasar Negara RI Tahun 1945, (Jakarta, 2004), hal. 12-13.
} 
kesapakatan-kesepakatan

tentang politik, hukum, pendidikan, kebudayaan, ekonomi, kesahjahteraan, dan aspek fundamental yang menjadi tujuan negara;

2. Konstitusi sebagai piagam kelahiran negara baru (a birth certificate of new state). Hal ini juga merupakan bukti adanya pengakuan masyarakat internasional, termasuk untuk menjadi anggota PBB, karena itu, sikap kepatuhan suatu negara terhadap hukum internasional ditandai dengan adannya ratifikasi terhadap perjanjian-perjanjian internasional;

3. Konstitusi sebagai sumber hukum tertinggi. Konstitusi mengatur maksud dan tujuan terbentuknya suatu negara dengan sistem administrasinya melalui adanya kepastian hukum yang terkandung dalam Pasal-Pasalnya, unifikasi hukum nasional, social control, memberikan legitimasi atas berdirinya lembaga-lembaga negara termasuk pengaturan tentang pembagian dan pemisahan kekuasaan antara organ legislatif, eksekutif, yudisial. Konstitusi sebagai sumber hukum tidak saja berfungsi sebagai a tool of social engeneering dan social control, melainkan juga harus mampu merespon secara kritis perubahan zaman;

4. Konstitusi sebagai indentitas nasional dan lambang persatuan. Konstitusi menjadi suatu sarana untuk memperlihatkan berbagai nilai dan norma suatu bangsadan negara, misalnya simbol demokrasi, keadilan, kemerdekaan, negara hukum, yang dijadikan sandaran untuk mencapai kemajuan dan keberhasilan tujuan negara. Konstitusi suatu negara diharapkan dapat menyatakan persepsi masyarakat dan pemerintah, sehingga memperlihatkan adanya nilai identitas kebangsaan, persatuan dan kesatuan, perasaan bangga dan kehormatan sebagai bangsa yang bermartabat. Konstitusi dapat memberikan pemenuhan atas harapanharapan sosial, ekonomi dan kepentingan politik. Konstitusi tidak saja mengatur pembagian dan pemisahan kekuasaan dalam lembaga-lembaga politik seperti legislatif, eksekutif, dan yudisial, akan tetapi juga mengatur tentang penciptaan keseimbangan hubungan (cheks and balances) antara pemerintah di pusat maupun di daerah;

5. Konstitusi sebagai alat untuk membatasi kekuasaan. Konstitusi dapat berfungsi untuk membatasi kekuasaan, mengendalikan perkembangan dan situasi politik yang selalu berubah, serta berupaya untuk menghindarkan adanya penyalahgunaan kekuasaan. Berdasarkan alasan tersebut, menjadi sangat penting diperhatikan seberapa jauh formulasi Pasal-Pasal dalam konstitusi dalam mengakomodasikan materi muatan-muatan pokok dan penting sehingga dapat mencegah timbulnya penafsiran yang beraneka ragam; 
6. Konstitusi sebagai pelindung HAM dan kebebasan warga negara. Konstitusi memberikan perlindungan terhadap hak-hak asasi manusia dan hak-hak kebebasan warga negara. Hal ini merupakan pengejahwantahan suatu negara hukum dengan ciri-ciri equality before the law, non diskriminatif dan keadilan hukum (legal justice) dan keadilan moralitas (social and moral justice).

Begitu pentingnya kedudukan Pembukaan UUD 1945 sehingga dalam periode perubahan UUD 1945 secara masif disepakati secara nasional bahwa Pembukaan ("Preambule") UUD 1945 untuk tidak diubah sama sekali. Amandemen pertama dilakukan pada Sidang Umum (SU) MPR 1999, lalu amandemen kedua berlangsung pada SU MPR 2000, amandemen ketiga diadakan pada Sidang Tahunan (ST) MPR 2001, dan terakhir amandemen keempat dilakukan pada ST MPR 2002. Pada keempat sidang inilah UUD 1945 mengalami banyak perubahan yang sifatnya mendasar, baik menyangkut substansi maupun menyangkut struktur kelembagaan negara.

\section{Simpulan}

Pembukaan, preambule, atau mukadimah dalam setiap dokumen konstitusi selalu berisikan pernyataan yang singkat tapi sungguh padat. Di dalamnya tertuang visi, misi, dan nilai-nilai dasar sebuah institusi atau organisasi sebagai wadah kebersamaan yang hendak dibangun dan dijalankan bersama. Selain itu juga merupakan pengantar hidmat berisi ide-ide politik, moral, dan keagamaan yang hendak dikemukakan oleh konstitusi tersebut. Pembukaan ini lebih mengandung karakter ideologis daripada karakter hukum.

Dalam konteks Indonesia, Pembukaan UUD 1945 adalah bagian terpenting dari UUD 1945 yang disepakati oleh MPR 1999 untuk tidak diubah sama sekali. Pembukaan dikatakan sebagai bagian terpenting karena disanalah tertuang norma fundamental negara (staatsfundamental norm), tujuan bangsa dan tujuan bangsa inilah merupakan hasil kontrak kenegaraan antara rakyat dan negara.

\section{DAFTAR PUSTAKA}

Asshidiqie, Jimly. Implikasi Perubahan UUD 1945 terhadap Pembangunan Hukum Nasional (Jakarta: Mahkamah Konstitusi RI, 2005). Pengantar Hukum Tata Negara Jilid 1. (Sekretariat Jenderal dan Kepaniteraan Mahkamah Konstitusi, Jakarta: 2006).

Bodenheimer, Edgar. Jurisprudence: The method and philosophy of law, (Cambridge: Harvard University Press, 1962).

Departemen Pendidikan Nasional. Kamus Besar Bahasa Indonesia. (Jakarta: Balai Pustaka, 2002).

Kelsen, Hans. Teori Umum tentang Hukum dan Negara. (Bandung: Penerbit Nusamedia, 2009).

Majelis Permusyawaratan Rakyat. Buku I Naskah Akademik Kajian Komprehensif Komisi Konstitusi tentang Perubahan Undang-Undang Dasar Negara RI Tahun 1945. (Jakarta, 2004). 
Fiat Justisia Jurnal Ilmu Hukum Volume 7 No. 2, Mei-Agustus 2013, $\quad$ ISSN 1978-5186

McIllwain, Charles Howard. Constitutionalism: Ancient and Modern. (Cornell University Press, 1947).

Orgad, Liav. The Preambule in Constitutional Interpretation. (International Journal of Constitutional Law 8, Oxford University, 2010).

Prodjodikoro, Wirjono. Azas-Azas Hukum Tata Negara di Indonesia. (Jakarta: Penerbit Dian Rakjat, 1983).

Simanjuntak, Augustinus. Refleksi 60 Tahun UUD 1945. Harian Surabaya Post, 12 Agustus 2005.

Sukardja, Ahmad. Piagam Madinah \& Undang-Undang Dasar NRI 1945. (Jakarta: Sinar Grafika, 2012).

Wheare, KC. Modern Constitution. (Oxford University Press, 1951) 